\title{
Kinetic Parameters of Rubidium Transport Pathways Are Normal in Cystic Fibrosis Red Cells
}

\author{
CLINTON H. JOINER
}

Department of Pediatrics, University of Alabama School of Medicine, Birmingham, Alabama 35294

\begin{abstract}
The abnormalities in ion transport in cystic fibrosis (CF) respiratory and sweat duct epithelia have prompted studies of ion permeability in CF red blood cells (RBC) although previous reports have been contradictory. In this study, the kinetic characteristics of the three major cation transport systems in $\mathbf{R B C}$ were evaluated by measuring rubidium $(\mathbf{R b})$ uptake at various external $\mathbf{R b}$ concentrations. The maximal velocity and affinity for external $\mathbf{R b}$ $\left(K_{1 / 2}\right)$ of the NaK pump were normal in CF RBC, as were the maximal velocity and $K_{m}$ for $\mathrm{Rb}$ of the NaK cotransport system. Residual (ouabain and bumetanide insensitive) $\mathbf{R b}$ uptake, and steady state $\mathrm{RBC} \mathrm{Na}$ and $K$ contents were also normal. These data indicate the $\mathrm{NaK}$ pump and cotransport system do not exhibit primary or secondary perturbations in $\mathrm{CF} \mathrm{RBC}$, and suggest that the noncarrier-mediated membrane permeability to cations is also normal in these cells. (Pediatr Res 24: 495-498, 1988)
\end{abstract}

\section{Abbreviations}

CF, cystic fibrosis

RBC, red blood cell

$V_{\max }$, maximal velocity

$\mathbf{K}_{\mathrm{o}}, \mathbf{R} \mathbf{b}_{\mathrm{o}}$, external $\mathbf{K}$ or $\mathbf{R b}$

PBS, phosphate-buffered saline

OS, ouabain-sensitive

Co, cotransport

$\mathrm{CF}$ is an autosomal recessive disorder manifesting multiple exocrine abnormalities (1). The diagnostically important elevation of sweat chloride reflects malfunctioning of the salt resorbing mechanisms of sweat duct epithelium. Recent work has indicated that the basis of this dysfunction is low $\mathrm{Cl}$ permeability of the apical membrane of the ductal epithelial cells (2). Respiratory epithelia share this defect (3), which appears in these cells to arise from abnormalities of the adrenergic regulatory mechanisms of the $\mathrm{Cl}$ channel (4-6). Other recent studies of $\mathrm{CF}$ respiratory epithelia have also shown increased permeability of the apical membrane to $\mathrm{Na}$, accompanied by elevated $\mathrm{Na}$ pump rates at the basolateral membrane, with increased numbers of $\left[{ }^{3} \mathrm{H}\right]$ ouabain binding sites and ouabain-inhibitable oxygen consumption (7). These findings suggest that, in addition to the $\mathrm{Cl}$ channel,

Received March 7, 1988; accepted June 14, 1988.

Correspondence and reprints Clinton H. Joiner, M.D., Ph.D., Division of Neonatology, Department of Pediatrics, University of Cincinnati College of Medicine, 231 Bethesda Avenue, Cincinnati, OH 45267.

Supported by a pilot project grant, funded by the Research Development Program Center Grant of the University of Alabama at Birmingham from the Cystic Fibrosis Foundation. certain cation transport systems might also be primarily or secondarily affected in $\mathrm{CF}$.

Numerous studies of cation transport in CF RBC have been prompted by the ready availability and ease of handling of this "biopsy" material and the advantage of interpreting results within the context of the relatively well understood cation transport systems of red cells. The results of early studies, however, were contradictory. Balfe et al. (8) found reduced Na pump activity (ouabain-sensitive $\mathrm{Na}$ efflux) in $\mathrm{CF}$ red cells compared to normal red cells, but this finding was not confirmed by Lapey and Gardner (9) using similar techniques, or by Hadden et al. (10), who found normal ouabain-sensitive ${ }^{86} \mathrm{Rb}$ uptake in $\mathrm{CF}$ red cells. Studies of NaK ATPase activity also produced conflicting results when comparing CF to normal RBC membranes (10,11). More recently, however, Reznik et al. (12) reported a reduced affinity of the NaK pump for external K(Rb): $K_{m}$ was $2.2 \mathrm{mM}$ for normal $\mathrm{RBC}$ and 4.6 in $\mathrm{CF} \mathrm{RBC}$. This finding paralleled their previous report that the affinity for external $\mathrm{K}$ of the $\mathrm{NaK}$ pump in cultured CF fibroblasts was reduced compared to normal cells (13), but both of these results are inconsistent with the finding of Boucher et al. (7) that CF respiratory epithelium had increased Na pump activity (7).

Assessments of the function of the NaK cotransport system in $\mathrm{CF} \mathrm{RBC}$ have been similarly ambiguous. The portion of $\mathrm{Na}$ efflux inhibited by ethacrinic acid (which was later found to block NaK cotransport) was reported by Balfe et al. (8) to be reduced in CF RBC, although Lapey and Gardner (9) observed this effect in male and not female CF patients, a phenomenon inconsistent with a single autosomal gene defect. Hadden et al. (10) found normal ethacrinic acid inhibitable ${ }^{86} \mathrm{Rb}$ uptake in CF $\mathrm{RBC}$. Interpretation of these studies is hampered by the fact that the $\mathrm{NaK}$ cotransport system was not well understood at the time they were published.

These discrepancies might have resulted from the variety of experimental procedures used, including the use of different ions $(\mathrm{Rb}, \mathrm{K}, \mathrm{Li})$ at different concentrations in the incubation media. Accordingly, physiologically important differences in the kinetic characteristics of the transport pathways studied might have been obscured. For this reason, and in view of the more recent reports of abnormaliteis in Na pump activity in CF red cells and other tissues $(7,12,13)$, kinetic parameters of three major cation transport pathways in red cells were measured: the NaK pump, the NaK Co system, and the ouabain and bumetanide insensitive (residual) pathway. The results indicate that all of these pathways are kinetically normal in CF red cells.

\section{MATERIALS AND METHODS}

To assess the kinetic characteristics of the potassium transport systems, net $\mathrm{Rb}$ uptake in red cells was measured, which approximates the unidirectional flux as long as internal $\mathrm{Rb}$ concentration remains low. The suitability of $\mathrm{Rb}$ as a substitute for $\mathrm{K}$ has 
been well documented for ion transport studies in the human red cell (14-16). Heparinized blood was obtained with informed consent under a protocol approved by the Institutional Review Board of the University of Alabama at Birmingham, from normal white volunteers (aged 22-50 yr, median $27 \mathrm{yr}$ ) or from ambulatory CF patients (aged 11-37 yr, median $16 \mathrm{yr}$ ) who were not taking digitalis derivatives or diuretics. Cells were washed three times in PBS, which contained (mM): $110 \mathrm{NaCl}, 20$ $\mathrm{Na}_{2} \mathrm{HPO}_{4}$ (pH 7.45), 0.1 EDTA, 10 tetramethylammonium-Cl, 10 glucose. Cells were incubated at $5-10 \%$ hematocrit in PBS with various concentrations of external $R b\left(R b_{o}, 0.4-50 \mathrm{mM}\right)$ with $\mathrm{Na}$ varying reciprocally $\left(\mathrm{Na}_{\mathrm{o}}=100-150 \mathrm{mM}\right)$. Flasks contained either ouabain $(0.1 \mathrm{mM})$, ouabain plus bumetanide $(0.05 \mathrm{mM})$, or no drug (control). Prewarmed cells were added at zero time, and triplicate samples were taken at $1 \mathrm{~h}$ and processed as described previously (17). Cells were lysed and the hemolysates assayed spectrophotometrically for $\mathrm{Hb}$ and for $\mathrm{Rb}$ by flame emission spectroscopy. $\mathrm{Rb}$ uptake was calculated as mmol/liter . cells/h. Supernatant $\mathrm{Rb}$ concentrations were measured in each incubation flask. This method has been validated in human (16) and sheep (18) red cells. My preliminary experiments showed that this "one point" method gave results equivalent to procedures involving multiple time points over a 2 -h period. Cellular $\mathrm{Na}$ and $\mathrm{K}$ were measured on fresh, washed cells using similar flame emission techniques.

$\mathrm{NaK}$ pump activity was calculated as the OS component of $\mathrm{Rb}$ uptake (uptake in control cells minus uptake in ouabaintreated cells) for each measured $\mathrm{Rb}_{\mathrm{o}}$ concentration. Results were plotted as OS Rb uptake versus $\mathrm{Rb}_{\circ}$ as shown in Figure $1 A$. Sachs and Welt (19) showed that simple Michaelis-Menten kinetics did not adequately describe the response of the NaK pump to external K. Indeed, Eadie-Hofstee plots of our data were so curved as to make analysis of $\mathrm{V}_{\max }$ and $K_{m}$ unthinkable. Therefore, the value of OS Rb uptake at $14-16 \mathrm{mM} \mathrm{Rb}$ was taken as $\mathrm{V}_{\max }$, and $\mathrm{K}_{1 / 2}$ was estimated graphically as the value of $\mathrm{Rb}_{\mathrm{o}}$ at which one-half $\mathrm{V}_{\max }$ was achieved. The data in Figure $1 \mathrm{~A}$ demonstrate that $\mathrm{OS} \mathrm{Rb}$ uptake clearly saturated at these $\mathrm{Rb}$ o concentrations and that $\mathrm{K}_{1 / 2}$ could be unambiguously determined by this method.

$\mathrm{NaK}$ cotransport was assayed as the ouabain-insensitive, bumetanide-sensitive $\mathrm{Rb}$ uptake (Co $\mathrm{Rb}$ uptake), calculated by subtracting $\mathrm{Rb}$ uptake of cells treated with ouabain and bumetanide from that of cells exposed to ouabain alone. For some concentrations of $\mathrm{Rb}_{\mathrm{o}}$, bumetanide incubations were omitted due to limitation in the volume of blood samples. However, because $\mathrm{Rb}$ uptake in the presence of both ouabain and bumetanide was linear with $\mathrm{Rb}_{\mathrm{o}}$ (see below), a value for ouabain- and bumetanide-insensitive uptake could be calculated at any $R b_{\circ}$ for which ouabain-insensitive $\mathrm{Rb}$ uptake was measured, allowing the calculation of $\mathrm{Co} \mathrm{Rb}$ uptake for all ouabain treated samples. The relationship of $\mathrm{Co} R \mathrm{R}$ uptake to $\mathrm{Rb} \mathrm{b}_{\circ}$ approximated a rectangular hyperbola (Fig. $1 B$ ) and linear plots of (Co Rb uptake) ${ }^{-1}$ versus $\left(\mathrm{Rb}_{\circ}\right)^{-1}$ were obtained (inset), allowing calculation of $\mathrm{V}_{\max }$ and $K_{m}$.

The component of $\mathrm{Rb}$ uptake in the presence of both ouabain and bumetanide (residual $\mathrm{Rb}$ uptake) has been shown to approximate the permeability of the lipid bilayer (20) in normal RBC. The linear, nonsaturating relationship between residual $\mathrm{Rb}$ uptake and $\mathrm{Rb}_{\mathrm{o}}$ was confirmed by the data in this study (Fig. $1 C$ ) for both normal and CF RBC. Plots of residual $\mathrm{Rb}$ uptake versus $\mathrm{Rb}_{\mathrm{o}}$ were straight lines with an average correlation coefficients ( $r$ ) of $0.997\left( \pm 0.003 \mathrm{SD}, n=20\right.$ ), and intercepts at zero $\mathrm{Rb}_{\mathrm{o}}$ which approximated naturally occurring $\mathrm{Rb}$ levels in $\mathrm{RBC}$, providing further validation of the $\mathrm{Rb}$ uptake method. The slope of such a plot (by least squares analysis) represents an apparent rate constant $\mathrm{k}$ (units: $\mathrm{mmol} / \mathrm{liter} \cdot \mathrm{cel} / \mathrm{h} / \mathrm{mM}$ ), which is related, but not equivalent to a rate coefficient (units: $\mathrm{h}^{-1}$ ).

All chemicals were reagent grade; water was predeionized and doubly distilled. Ouabain was obtained from Sigma Chemical Co., (St. Louis, MO); bumetanide was a gift from HoffmanLaRoche, Inc. (Nutley, NJ).

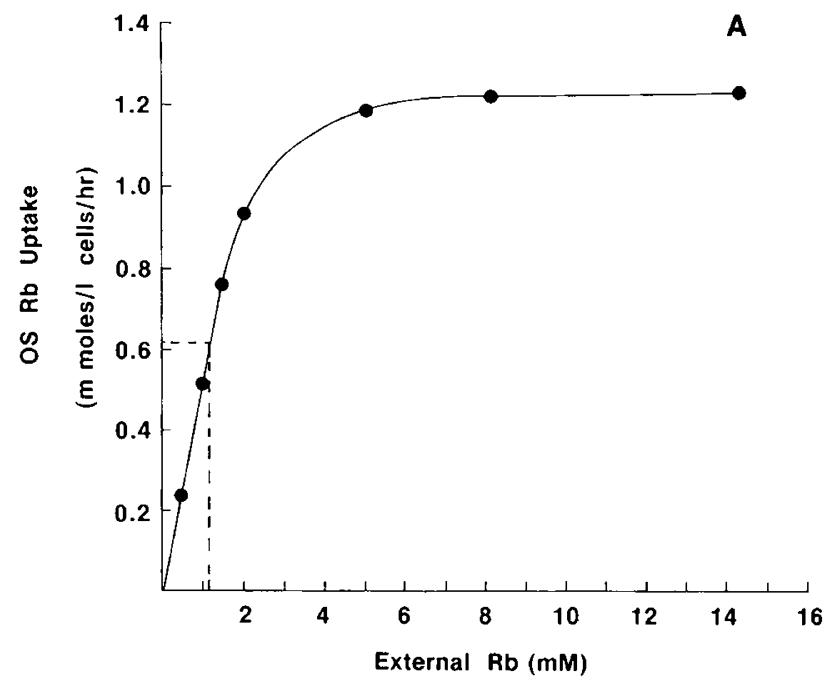

B

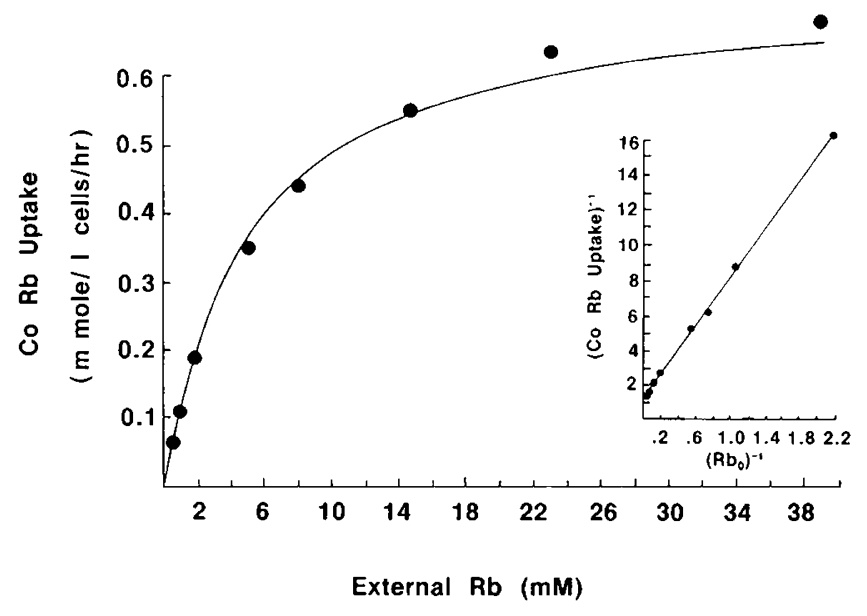

C

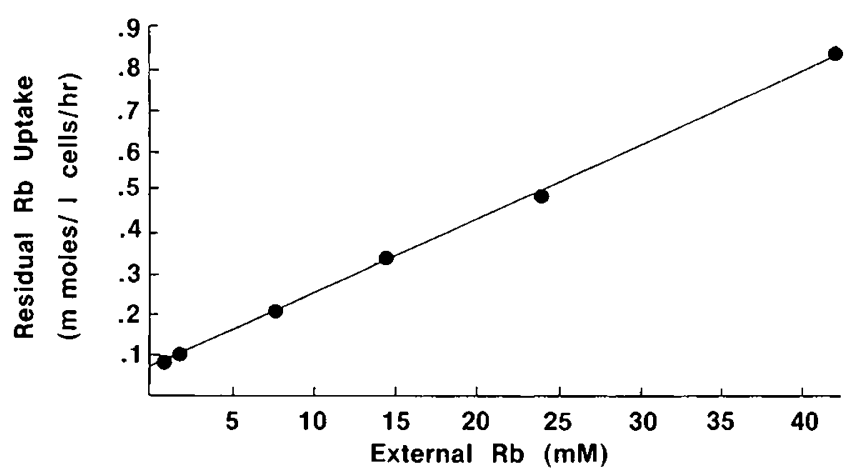

Fig. 1. Concentration dependence of rubidium uptake in normal red cells. Each panel represents data from a single experiment. Points are means of triplicate determinations, the SD of which were smaller than the points as shown. $A$, OS Rb uptake versus $\mathrm{Rb}_{0} . \mathrm{V}_{\max }$ from the data of this experiment is $1.23 \mathrm{mmol} / \mathrm{liter}$. cells $/ \mathrm{h} ; \mathrm{Rb}_{0}$ concentration at $1 / 2$ $\mathrm{V}_{\text {max }}\left(\mathrm{K}_{1 / 2}\right)$ was $1.1 \mathrm{mM}$, as shown by dotted lines. $B$, Ouabain-insensitive, bumetanide-sensitive (Co) $\mathrm{Rb}$ uptake versus $\mathrm{Rb}_{\mathrm{o}}$. The curve depicted is the rectangular hyperbole defined by $K_{m}$ and $\mathrm{V}_{\max }$ calculated from the double reciprocal plot shown in the inset. $C$, Ouabain- and bumetanideinsensitive (residual) $\mathrm{Rb}$ uptake versus $\mathrm{Rb}_{0}$. Slope was $0.0183 \mathrm{mmol} /$ liter.cells $/ \mathrm{h} / \mathrm{mM}, r=0.9996$; intercept was $0.067 \mathrm{mmol} / \mathrm{liter} \cdot$ cells $/ \mathrm{h}$, compared to a measured naturally occurring $\mathrm{Rb}$ level of $0.068 \pm 0.002$ $\mathrm{mmol} /$ liter. cells. 


\section{RESULTS}

Table 1 below shows cellular $\mathrm{Na}$ and $\mathrm{K}$ contents in $\mathrm{RBC}$ from $10 \mathrm{CF}$ patients and 10 normal controls, along with the kinetic parameters of $\mathrm{K}(\mathrm{Rb})$ influx mediated by the $\mathrm{NaK}$ pump, $\mathrm{NaK}$ Co system, and residual pathway. Steady-state monovalent cation contents were not different in $\mathrm{CF} \mathrm{RBC}$ from normal $\mathrm{RBC}$, confirming the findings of other investigators $(10,11)$. It is especially important to note that cellular $\mathrm{Na}$ is normal in $\mathrm{CF}$ cells because this allows analysis of external $\mathrm{NaK}$ pump kinetics with the assurance that the degree of pump activation by internal $\mathrm{Na}$ is the same in CF and normal cells. Without this information, comparisons of the kinetic constants of the pump (especially $\mathrm{V}_{\max }$ ) between the two cell types cannot be made. Normal internal cation concentrations also insure that the driving forces for Co-mediated uptake are equivalent for normal and CF cells.

External $K(R b)$ affinity $\left(K_{1 / 2}\right)$, as well as $V_{\max }$ of the NaK pump were virtually the same in CF and control RBC (Table 1). The scatter plots of these parameters are shown in Figure 2, which

Table 1. Cation transport parameters in normal and $C F R B C$ measured as Rb uptake*

\begin{tabular}{llcc}
\hline & & Normal & CF \\
\hline Cellular cations $\dagger$ & $\mathrm{Na}$ & $8.7(2.8)$ & $8.3(1.5)$ \\
& $\mathrm{K}$ & $92.4(9.2)$ & $98.8(7.7)$ \\
& & $(n=7)$ & $(n=10)$ \\
NaK pump $\S$ & $\mathrm{K}_{1 / 2 \ddagger}$ & $1.13(0.15)$ & $1.21(0.14)$ \\
& $\mathrm{V}_{\max } \|$ & $1.98(0.34)$ & $1.93(0.46)$ \\
& & $(n=10)$ & $(n=10)$ \\
NaK Cof & & & \\
& $K_{m}$ & $4.18(0.85)$ & $5.12(1.24)$ \\
& $\mathrm{V}_{\max }$ & $0.916(0.400)$ & $0.645(0.250)$ \\
& & $(n=10)$ & $(n=10)$ \\
Residual Rb permeability & $\mathrm{k}^{* *}$ & $0.0181(0.0030)$ & $0.0183(0.0055)$ \\
& & $(n=10)$ & $(n=10)$ \\
\hline
\end{tabular}

* Cellular cations and kinetic parameters were measured as described in "Materials and methods" and illustrated in Figure 1. Data are presented as means (SD) of single determinations in $n$ individuals.

$\dagger \mathrm{mmol} / \mathrm{liter} \cdot$ cells.

$\neq \mathrm{mM}$.

$\S$ Ouabain-sensitive $\mathrm{Rb}$ uptake.

$\| \mathrm{mmol} / \mathrm{liter} \cdot$ cells/h.

I Ouabain-insensitive, bumetanide-sensitive $\mathrm{Rb}$ uptake.

** Rate constant for ouabain- and bumetanide-sensitive $\mathrm{Rb}$ uptake, $\mathrm{mmol} / \mathrm{liter} \cdot$ cells/h/mM. illustrates clearly the tight distributions of these kinetic constants of the NaK pump for both $\mathrm{CF}$ and normal populations. These data contrast markedly with those of Reznik et al. (12) who found a 2-fold increase in $K_{m}$ for external $\mathrm{K}(\mathrm{Rb})$. For the data reported here, the probability of a type II $(\beta)$ error for failing to detect a two-fold increase in $\mathrm{K}_{1 / 2}$ is less than 0.001 . Indeed, the current data would have a $95 \%$ probability of demonstrating a difference in $\mathrm{K}_{1 / 2}$ as small as $20 \%$, based on power analysis for a 2-tailed $t$ test with $n=10$ using a 0.05 significance criterion (21). In agreement with Reznik et al. (12), I found no difference in NaK pump $V_{\max }$ between $C F$ and normal $R B C$, although in their study $\mathrm{V}_{\max }$ was $40 \%$ lower than reported here.

Interindividual variability in the measurements of $K_{m}$ and $\mathrm{V}_{\max }$ of the $\mathrm{NaK}$ cotransport system was much greater than those of NaK pump activity, consistent with the observations in studies of larger populations (22-24). Although the $\mathrm{Co} \mathrm{V}_{\max }$ for $\mathrm{Rb}$ was slightly lower and the $K_{m}$ was slightly higher in CF RBC (Table $1)$, these differences were not statistically significant. The probability by unpaired $t$ test for a difference between the two groups was 0.10 for $\mathrm{V}_{\max }$ and 0.06 for $K_{m}$, without consideration of multiple analyses that would tighten significance criteria. In view of the finding of Lapey and Garner (9) that male but not female $\mathrm{CF}$ patients showed reduced ethacrinic acid sensitive $\mathrm{Na}$ efflux, Co $\mathrm{V}_{\max }$ and $K_{m}$ in $\mathrm{CF}$ and normal $\mathrm{RBC}$ were examined for gender-associated differences, and none was observed (data not shown). The scatter plots of these data (Fig. 3) demonstrate that for both cotransport $K_{m}$ and $\mathrm{V}_{\max }$, the CF and normal populations cluster together, with approximately $80 \%$ overlap of distributions. In the case of $\mathrm{V}_{\max }$ in particular, the major contribution to the difference between groups comes from two outlying points. Clearly these parameters are not useful predictors of CF phenotype, and these data are not consistent with a primary or secondary defect in $\mathrm{CF}$ reflected in the $\mathrm{NaK}$ cotransport system.

The rate constant, $\mathrm{k}$, for ouabain- and bumetanide-insensitive $\mathrm{Rb}$ uptake was identical in $\mathrm{CF}$ and normal RBC (Table 1). This indicates at the basal permeability of the membrane to $K(R b)$ is normal in CF RBC. Direct measurements of $\mathrm{Na}$ permeability are very difficult in $\mathrm{RBC}$ because of the high rate of $\mathrm{Na}: \mathrm{Na}$ exchange, but this finding makes it unlikely that there is a nonspecific increase in cation permeability in CF RBC.

\section{DISCUSSION}

This study has demonstrated that the major cation transport pathways capable of net $\mathrm{Na}$ and $\mathrm{K}$ movements are normal in $\mathrm{CF}$ red blood cells. The $\mathrm{NaK}$ pump and $\mathrm{NaK}$ cotransport are normal in CF cells with respect to both their maximal velocities and affinities for external $\mathrm{K}(\mathrm{Rb})$. These results conflict with the

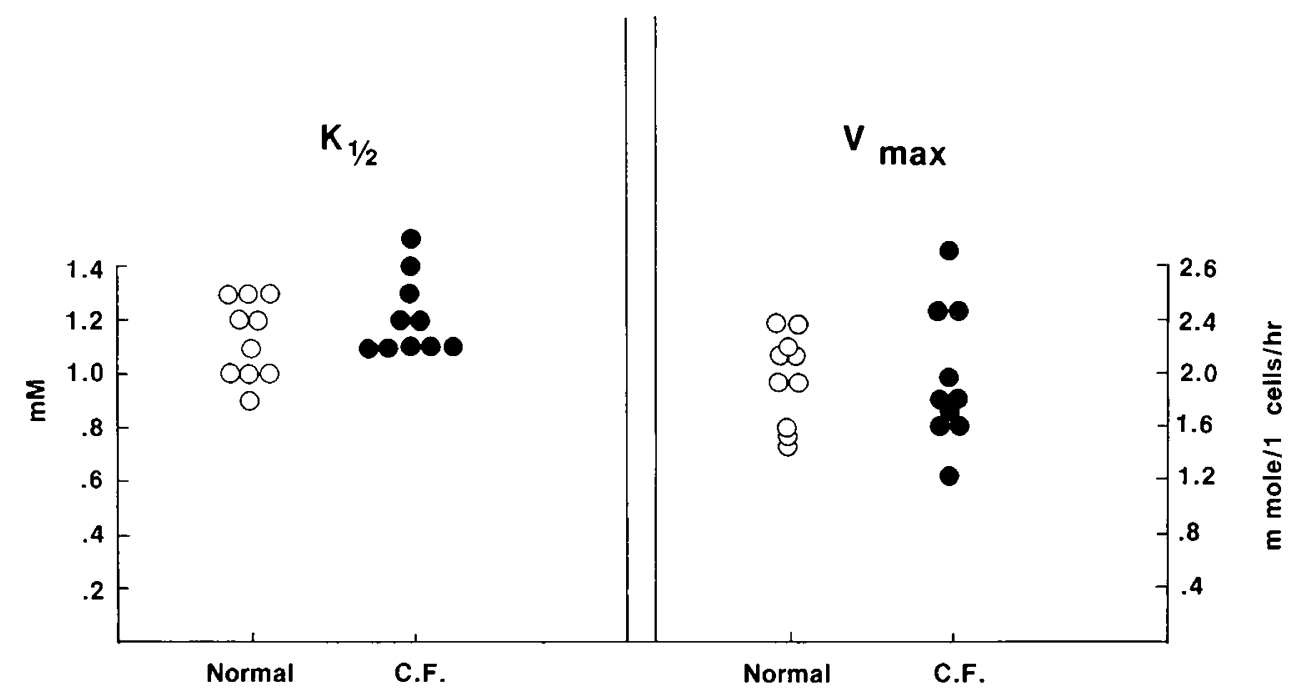

Fig. 2. Kinetic parameters of the $\mathrm{NaK}$ pump in normal and $\mathrm{CF}$ red cells. $\mathrm{V}_{\max }$ and affinity for external $\mathrm{Rb}\left(\mathrm{K}_{1 / 2}\right)$ were determined as described in "Materials and Methods" and illustrated in Figure 1A. Means and SD of these data are found in Table 1. 


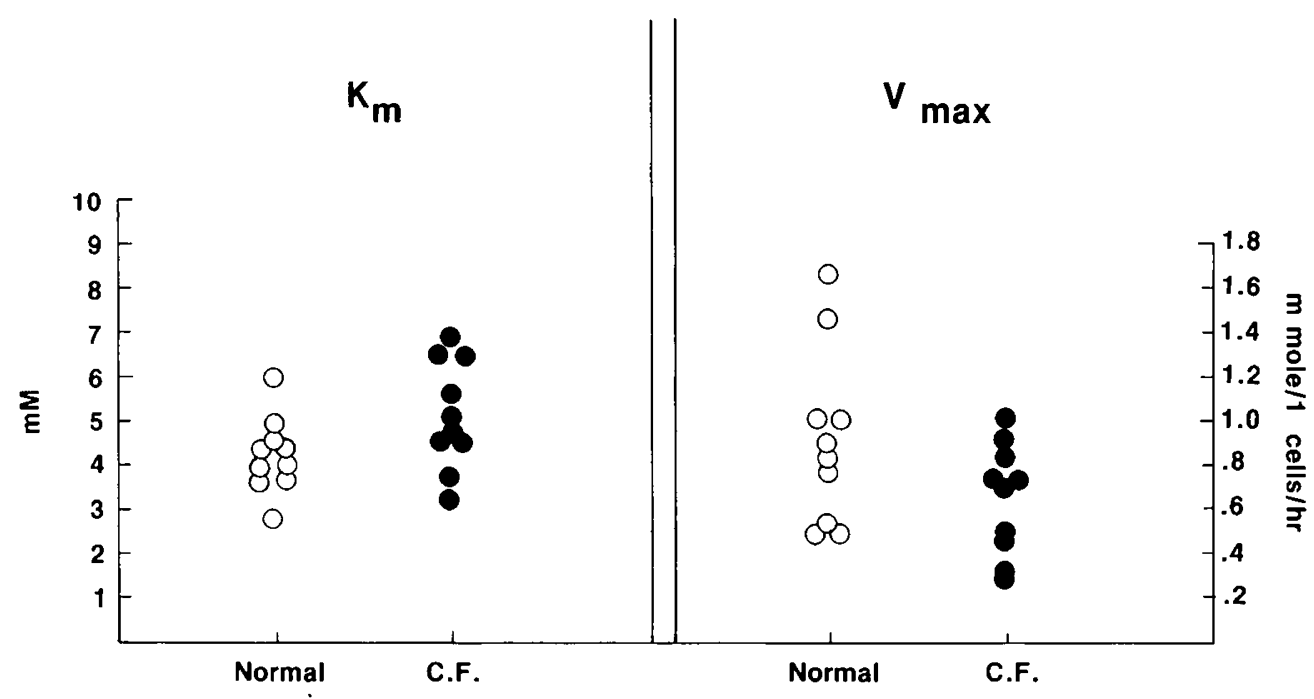

Fig. 3. Kinetic parameters of the $\mathrm{NaK}$ cotransport system in normal and $\mathrm{CF}$ red cells. $\mathrm{V}_{\max }$ and affinity for external Rb $\left(K_{m}\right)$ were determined as described in "Materials and Methods," and illustrated in Figure $1 B$. Means and SD of these data are found in Table 1.

decreased $\mathrm{K}(\mathrm{Rb})$ affinity of the NaK pump in CF $\mathrm{RBC}$ reported by Reznik et al. (12). The reasons for this discrepancy are not apparent, although we found that the Michaelis-Menten formulation used by Reznik et al. (12) did not adequately describe the kinetics of $\mathrm{Rb}_{\mathrm{o}}$ interaction with the $\mathrm{NaK}$ pump, in agreement with the earlier work of Sachs and Welt (19). The $K_{1 / 2}$ and $V_{\max }$ measured in the presence of high external $\mathrm{Na}$ for normal $\mathrm{RBC}$ in this study $(1.1 \mathrm{mM}$ and $1.98 \mathrm{mmol} / \mathrm{cells} / \mathrm{h} /$ liter $\cdot$ cells $)$ are in close agreement with the values for these parameters under comparable conditions reported originally by Sachs and Welt $(1.2 \mathrm{mM}$ and $1.67-1.85 \mathrm{mmol} /$ liter.cell/h) (19). Given the normal cellular Na content of CF RBC, our finding of a normal NaK pump $V_{\max }$ provides indirect evidence that the number of pump sites on CF RBC is normal. Thus, the increased Na pump rate and numbers of $\left[{ }^{3} \mathrm{H}\right]$ ouabain binding sites of $\mathrm{CF}$ respiratory epithelial cells (7) are not paralleled in the red cell. Similarly, the kinetic characteristics of the $\mathrm{NaK}$ Co system of CF RBC were found to be normal in this study.

The residual permeability of $\mathrm{CF} R B C$ to $\mathrm{Rb}$ was also normal, suggesting that a nonspecific cation permeability defect does not exist. This conclusion is further supported by normal intracellular cation concentrations and pump and Co rates in CF RBC, because a cell with elevated $\mathrm{Na}$ or $\mathrm{K}$ permeability would be expected on theoretical grounds to show abnormalities in one or more of these values (25). Moreover, in view of normal internal cation contents and external cation transport kinetics in $\mathrm{CF}$ $\mathrm{RBC}$, the hypothesis that perturbations exist in these cells in the internal kinetics of these pathways is extremely unlikely. Accordingly, further exploration of internal pump or cotransport kinetics does not seem warranted and was not undertaken in this study.

Boucher et al. (26) have presented evidence that conductive anion $\left(\mathrm{Cl}^{-}\right)$permeability in $\mathrm{CF} \mathrm{RBC}$ is also normal, indicating that the defect in $\mathrm{Cl}$ permeability or $\mathrm{Cl}$ channel regulation manifest in sweat duct and respiratory epithelium (2-6) is not present in RBC. It would appear, therefore, that the RBC is of limited use either as model system for the study of CF membrane transport abnormalities or as the source of phenotypic markers of abnormal ion transport in $\mathrm{CF}$.

Acknowledgments. The author is indebted to Dr. Raymond Lyrene for obtaining patient blood samples, to Wayne Baird for technical assistance, and to Cassandra Bailey for typing the manuscript.

\section{REFERENCES}

1. di Sant' Agnese PA, Davis PB 1976 Research in cystic fibrosis. J Engl J Med 29:507-602
2. Quinton PM 1983 Chloride impermeability in cystic fibrosis. Nature 301:421422

3. Knowles MR, Gatzy JT, Boucher RC 1983 Relative ion permeability of normal and cystic fibrosis nasal epithelium. J Clin Invest 71:1410-1417

4. Widdicombe JH, Welsh MJ, Finkbeiner WE 1985 Cystic fibrosis decreases the apical membrane chloride permeability of monolayers cultured from cells of tracheal epithelium. Proc Natl Acad Sci USA 82:6167-6171

5. Sato K, Sato F 1984 Defective beta adrenergic response of cystic fibrosis sweat glands in vivo and in vitro. $J$ Clin Invest 73:1763-1771

6. Frizzell RA, Rechkemmer G, Shoemaker RL 1986 Altered regulation of airway epithelial cell chloride channels in cystic fibrosis. Science 233:558-560

7. Boucher RC, Stutts MJ, Knowles MR, Cantly L, Gatzy JT $1986 \mathrm{Na}^{+}$transport in cystic fibrosis respiratory epithelia: Abnormal basal rate and response to adenylate cyclase activation. J Clin Invest 78:1245-1252

8. Balfe JW, Cole C, Welt LG 1968 Red-cell transport defect in patients with cystic fibrosis and their parents. Science 162:689-690

9. Lapey A, Gardner JD 1971 Abnormal erythrocyte sodium transport in cystic fibrosis of the pancreas. Pediatr Res 5:446-451

10. Hadden JW, Hansen LG, Shapiro BL, Warwick WJ 1972 Erythrocyte enigmas in cystic fibrosis. Proc Soc Exp Biol Med 142:577-579

11. Cole CH, Dirks JH 1972 Changes in erythrocyte membrane ATPase in patients with cystic fibrosis of the pancreas. Pediatr Res 6:616-621

12. Reznik VM, Harwood I, Mendoza SA $1986 \mathrm{~K}$ dependence of the Na-K pump is abnormal in erythrocytes from patients with cystic fibrosis and obligate heterozygotes. Biochem Biophys Res Commun 137:1021-1027

13. Reznik VM, Schneider Mendoza SA $1981 \mathrm{Na}$ and K dependence of the Na/K pump in cystic fibrosis fibroblasts. Proc Natl Acad Sci USA 78:7143-7146

14. Geck P, Heinz E 1986 The Na-K-2Cl cotransport system. J Memb Biol 91:97105

15. Bernstein JC, Israel $Y 1970$ Active transport of ${ }^{86} \mathrm{Rb}$ in human red cells and rat brain slices. J Pharmacol Exp Ther 174:323-327

16. Duhm J, Goebel BO 1982 Sodium-lithium exchange and sodium-potassium cotransport inhuman erythrocytes: I. Evaluation of a simple uptake test to assess the activity of the two transport systems. Hypertension 4:468-476

17. Joiner CH, Lauf PK 1978 The correlation between ouabain binding and $K$ pump inhibition in human and sheep erythrocytes. J Physiol 283:155-175

18. Lauf PK 1983 Thiol-dependent passive $\mathrm{K} / \mathrm{Cl}$ transport in sheep red cells: I Effect of anion replacement and external cations. J Membr Biol 73:237-246

19. Sachs JR, Welt LG 1967 The concentration dependence of active potassium transport in the human red blood cell. J Cell Invest 46:65-76

20. Beauge L, Lew VL (Ed) 1977 Passive fluxes of sodium and potassium across red cell membranes. In: Membrane Transport in Red Cells. Academy Press, London, pp 39-52

21. Cohen J 1977 Statistical Power Analysis for the Behavior Sciences. Academic Press, New York

22. Duhm J, Gobel BO, Lorenz R, Weber PC 1982 Sodium-Lithium exchange and sodium-potassium cotransport in human erythrocytes: II. A simple uptake test applied to normotensive and essential hypertensive individuals. Hypertension 4:477-482

23. Tuck ML, Gross C, Maxwell MH, Brickman AS, Krasnoshtein G, Mayes D 1984 Erythrocyte $\mathrm{Na}^{+}, \mathrm{K}^{+}$cotransport and $\mathrm{Na}^{+}, \mathrm{K}^{+}$pump in black and caucasian hypertension patients. Hypertension 6:536-544

24. Weder AB, Torretti BA, Julius S 1984 Racial differences in erythrocyte cation transport. Hypertension 6:115-123

25. Lew VL, Bookchin RM 1986 Volume, pH, and ion-content regulation in human red cells: Analaysis of transient behavior with an integrated model. J Membr Biol 92:57-74

26. Boucher RC, Ross DW, Knowles MR, Gatzy JT, Parker JC $1984 \mathrm{Cl}^{-}$Permeabilities in red blood cells and peripheral blood lymphocytes from cystic fibrosis and control subjects. Pediatr Res 18:1336-1339 